\title{
Kén- és szeléntartalmú glikomimetikumok szintézise
}

\author{
SZABÓ Tamás* \\ Richter Gedeon Nyrt., Gyömröi út 19-21., 1103 Budapest, Magyarország
}

\section{Bevezetés}

Az állati és humán sejtfelszín fontos alkotórészei a glikánok, melyek számos fiziológiai felismerési folyamatban alapvető szerepet játszanak. ${ }^{1}$ A glikozilázok és glikozil transzferázok által szigorúan szabályozott folyamatban létrejövő glikán szekvenciák és fürtformák által tárolt óriási mennyiségü információt gyakran a sejtek ,ujjlenyomataként” vagy „cukor kódként” is említik. ${ }^{2-4} \mathrm{Az}$ információ kiolvasásának egyik módja a megfelelő szénhidrát receptorokkal történő kölcsönhatáson alapul. Ezek a fehérje-glikán felismerési folyamatok az utóbbi években egyre nagyobb figyelmet kaptak..$^{5-7}$ Ezen folyamatokban résztvevő fehérjék legismertebb képviselői a lektinek, ${ }^{8}$ amelyeket először növényekből izoláltak. Növényi lektinekről általánosságban igaz, hogy a növény védelmét szolgálják. Ilyen például a Viscum album agglutinin (VAA) növényi toxin. ${ }^{9}$

Az állati szervezetekben előforduló lektineknek ennél szélesebb körü funkcióit ismerjük. Részt vesznek sejten belüli válaszreakciók kiváltásában, a sejt-sejt, a sejt-sejt közi állomány kölcsönhatásaiban. ${ }^{10}$ Egyik legnépesebb családjuk a galektinek. Elnevezésük ellenére gyengén kötnek $\beta$-galaktózt és általában laktózra vagy $\mathrm{N}$-acetillaktózaminra specifikusak. ${ }^{11}$ A galektinek rendellenes szabályozása, főként túlzott termelődése jelentős szerepet játszik több patológiai folyamatban, mint pl. a reumatoid artritis, gyulladások, fibrózis vagy a rák. ${ }^{12-14}$

A makromolekuláris glikánok és lektinek közötti kölcsönhatást kis molekulájú szénhidrátokkal illetve szénhidrát mimetikumokkal is modellezhetjük. Ilyen például a szelektinek gátlására kifejlesztett szialil Lewis-X, amely klinikai vizsgálatokban hatásosan gátolta az iszkémiával érintett testrészek újbóli vérellátásakor fellépő allergiás reakciót, ${ }^{15}$ vagy a Bimosiamose (1. ábra), amely asztmás betegeknél hatásos a légutakban megjelenő gyulladás visszaszorítására. ${ }^{16}$
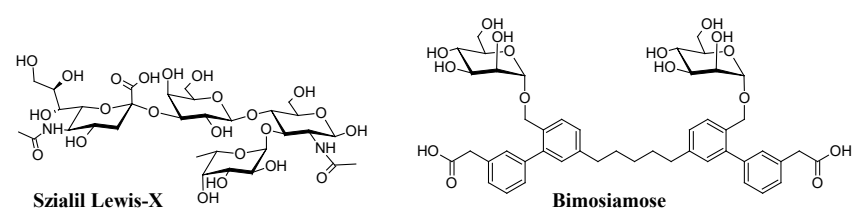

1. Ábra. Szelektin gátlószerek

A galektin-családból a legtöbb figyelem az 1- és 3-mal jelölt variánsokra (Galektin-1, Galektin-3) irányult. A Galektin- 3-gátló származékok közül leghatásosabbnak a galaktóz C-3 szénen módosított szimmetrikus digalaktozil tio-glikozidok, illetve a laktóz C-1-en módosított multivalens származékok bizonyultak. ${ }^{17}$ A TD1311 nevü származék hatékonyan csökkentette a pajzsmirigy tumorsejtek ellenállását, különösen doxorubicinnel, illetve ionizáló sugárzással kombinálva. ${ }^{18}$ Hasonló módon a laktulozil-L-leucin (2. ábra) a Taxol indukált apoptózist erősítette. ${ }^{19}$ A Galektin-1 és Galektin-3 szerepe ellentétes egymással, ezért a szelektív gátlás elősegítésére több szerkezetoptimálást is végeztek. Kiemelkedően magas szelektivitást tudtak elérni a galaktóz C-2 epimer (TDT, 2. ábra) talózszármazékkal. ${ }^{20}$
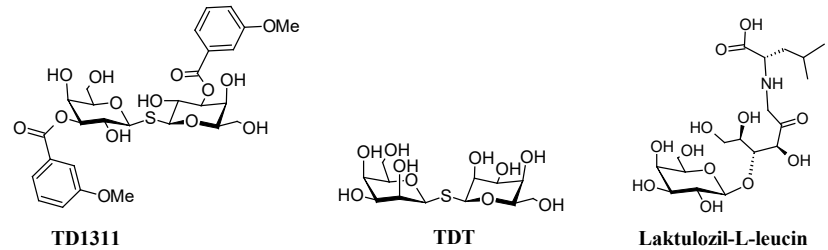

2. Ábra. Galektin gátlószerek

Célul tűztük ki toxikus növényi agglutininek, illetve az emberi szervezetre káros lektinek gátlására alkalmas további glikomimetikumok szintézisét. Előnyös, ha ezek a szénhidrát származékok olyan glikozidos kötéseket tartalmaznak, amelyek ellenállóak glikozidáz enzimekkel szemben.

\section{Eredmények}

A lektingátlási vizsgálatok céljára olyan bivalens tio-, diszulfido-, szeleno-, és 1,2,3-triazolo-glikozidokat állítottunk elö, amelyek központi aromás magként benzol-, naftalin-, ${ }^{21}$ vagy 1,5-diazabiciklo[3.3.0]okta-3,6-dién-2,8-dion („bimán”) vázat tartalmaztak. ${ }^{22}$ A szénhidrát egységeket tekintve galaktóz, laktóz, glükóz és mannóz származékokat állítottunk elő.

\section{Glikozilezett benzol és naftalin származékok szintézise}

A 22 1,4-bisz(brómmetil)naftalint $\mathbf{1 5}(\mathbf{b}, \mathbf{d})$ per- $O$-acetil-D-glikopiranozil tiolokkal reagáltatva a 26, 27 tio-glikozidokat, míg a 20, 22, 25, 28, 29 bisz(brómmetil)aréneket 17b 2,3,4,6-tetra- $O$-acetil- $\beta$-D-galaktopiranozil szelenourónium bromiddal reagáltatva 30-34 szeleno-glikozidokat kaptunk (3. ábra). 


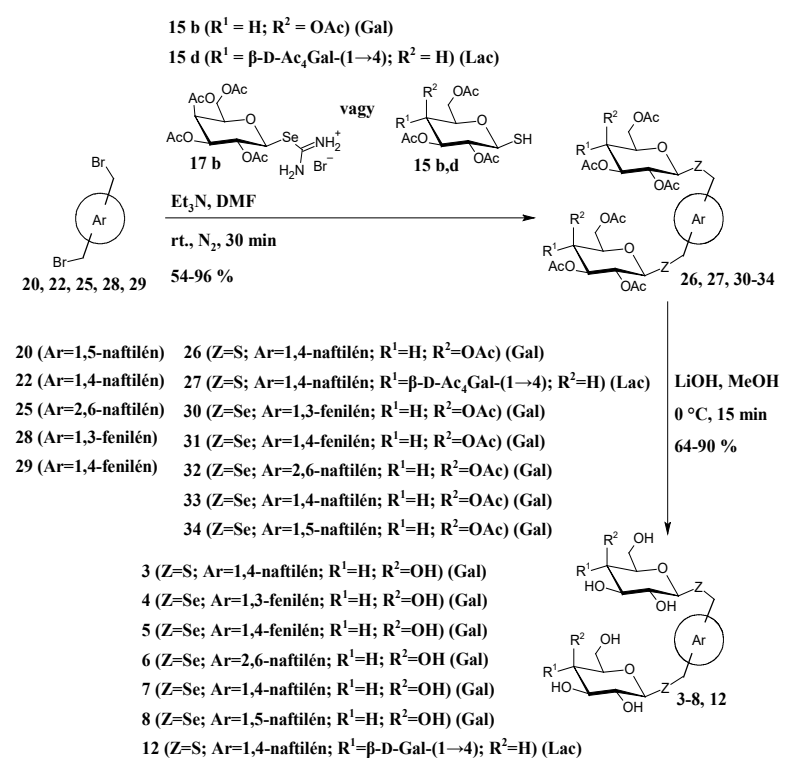

3. Ábra. Naftalin és benzol központi vázas tio- és szeleno glikozidok előállítása

A 38-40 bisz(metánszulfoniltiometil)-arén származékok és 15(b,d) per- $O$-acetil-D-glikopiranozil-tiolok kapcsolásával nyertük a 41-45 teljesen acetilezett származékokat (4. ábra). A 41-45, 26, 27, 30-34 benzol és naftalin alapvázra kapcsolt szénhidrát egységek acetil védőcsoportjait sztöchiometrikus mennyiségű lítium-hidroxiddal eltávolítva jó hozammal kaptunk 1-12 szabad cukor származékokat (3., 4. ábra).

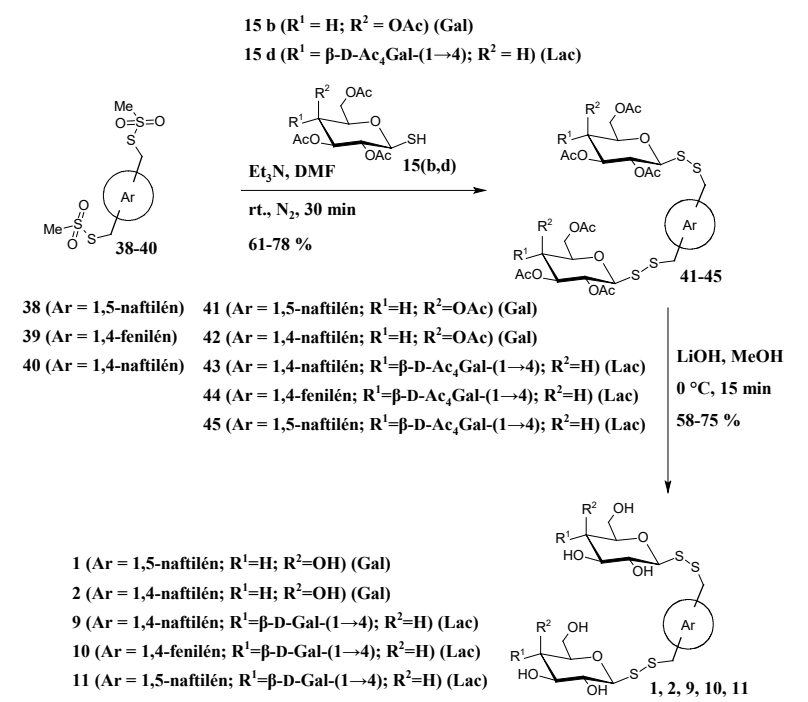

4. Ábra. Naftalin és benzol központi vázas diszulfido glikozidok elöállítása

\section{Glikozilezett benzol- és naftalin származékok jellemzése és biológiai aktivitása}

Az 1-12 vegyületek közül kiválasztott jellemző példák konformációs tulajdonságait molekuladinamikai számításokkal Dr. Fehér Krisztina (Debreceni Egyetem Szervetlen Kémiai Tanszék) térképezte fel. Az aromás maghoz kapcso- lódó két glikozil egység orientációja az anomer (C-1) atomjainak távolságával jellemezhető. A 4, 5 szelenogalaktozidok illetve 9, 11 diszulfido laktozidok esetében ezek a 4-11 Å között változó távolságok azt mutatták, hogy a glikozidos kötés körüli rotáció révén a molekulák csaknem az egész rendelkezésre álló konformációs teret képesek betölteni. ${ }^{21}$

Az 1-12 vegyületek biológiai aktivitását Prof. Hans-Joachim Gabius és csoportja vizsgálta (Ludwig Maximillians Egyetem, München). A származékok lektin-glikán kölcsönhatásra gyakorolt inhibíciós aktivitásait három különböző rendszeren tesztelték. A szilárd fázisú próbák során a felülethez rögzített glikoproteinröl (aszialofetuin) a VAA lektint a $\mathbf{2}$ diszulfid és a $\mathbf{6}$ szelenoszulfid az alap szénhidrátnál tízszer hatékonyabban szorította le. Az áramlásos citofluorometriai mérésekben a humán tumor sejtvonalak sejtfelszíni glikánjain három különböző humán galektin kötődését is a 9 diszulfid gátolta a leghatékonyabban. A komplexebb rendszerek felé tett lépésként a naftalin alapú glikokonjugátumok inhibíciós hatását hisztokémiai módszerekkel egér szövetmetszeteken tesztelték. Ezen vizsgálatokban a 9 és 12 vegyületek kiemelkedő hatékonyságúnak bizonyultak a humán galektinek szöveti kötődésének gátlásában. A Galektin- 8 kötődését rögzített egér vékonybél szöveten a laktózt tartalmazó 9-es vegyület százszor jobban gátolta, mint a szabad laktóz (1. táblázat). ${ }^{21}$

\begin{tabular}{lcccc}
\hline & VAA & Galektin & Galektin & Galektin \\
& lektin & -1 & -3 & -8 \\
\hline Vegyület & $\mathbf{2} / 0,5 \mathrm{mM}$ & $\mathbf{9} / 0,15 \mathrm{mM}$ & $\mathbf{9} / 25 \mu \mathrm{M}$ & $\mathbf{9} / 25 \mu \mathrm{M}$ \\
/IC50 & $\mathbf{6} / 1,0 \mathrm{mM}$ & & $\mathbf{1 2} / 50 \mu \mathrm{M}$ & $\mathbf{1 2} / 50 \mu \mathrm{M}$ \\
\hline
\end{tabular}

1. Táblázat. Leghatásosabbnak bizonyult glikozilezett benzol és naftalin származékok
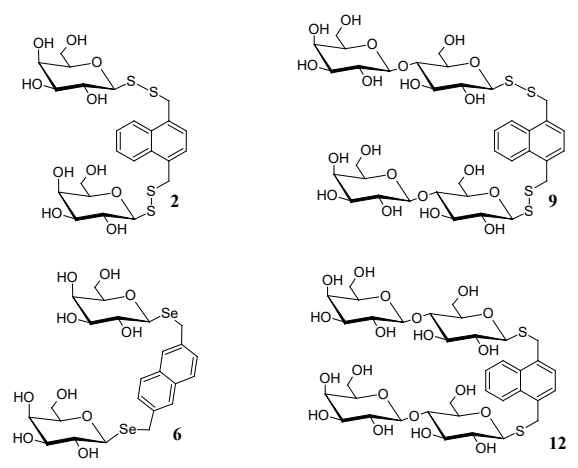

\section{Glikozilezett bimán származékok szintézise}

Ezen eredmények fényében célul tüztük ki újabb központi aromás maggal rendelkező glikozil mimetikumok szintézisét. Választásunk az 1,5-diazabiciklo[3.3.0]okta3,6-dién-2,8-dion (,bimán”) vázra esett, mert viszonylag kis molekulatömegü, több helyen funkcionalizálható, és a $s z \ddot{u} n$-izomer erősen fluoreszcens. ${ }^{23}$ 


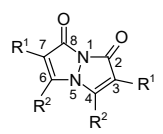

$s z \ddot{u} n-\left(\mathbf{R}^{2} ; \mathbf{R}^{1}\right) \mathrm{B}$

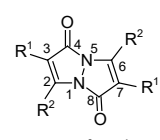

anti- $\left(\mathrm{R}^{2} ; \mathrm{R}^{1}\right) \mathrm{B}$

5. Ábra. szün- és anti-bimán váz szerkezete a Kosower et al. ${ }^{23}$ által bevezetett kompakt jelölésmóddal

A bimán vázat (5. ábra) elsőként E. M. Kosower és munkatársai állították elő. Az általuk leírt brómozás mind a szün mind az anti tetrametil-bimánok $\left(\mathrm{CH}_{3} ; \mathrm{CH}_{3}\right)$ B esetén szelektív, a $\left(\mathrm{CH}_{2} \mathrm{Br} ; \mathrm{CH}_{3}\right) \mathrm{B}$ dibróm-bimán származékokat szolgáltatja. ${ }^{23}$

A 62 szün- és 63 anti- $\left(\mathrm{CH}_{2} \mathrm{Br} ; \mathrm{CH}_{3}\right)$ B származékokat a 15(ad) per- $O$-acetil-D-glikopiranozil-tiolokkal reagáltatva a 64(a-d), 65(a-d) tio-glikozidokat, míg a 17(a-c) 2,3,4,6-tetra- $O$-acetil- $\beta$-D-glikopiranozil szelenourónium bromidokkal reagáltatva 66(a,b), 67(a-c) szeleno-glikozidokat kaptunk (6. ábra).

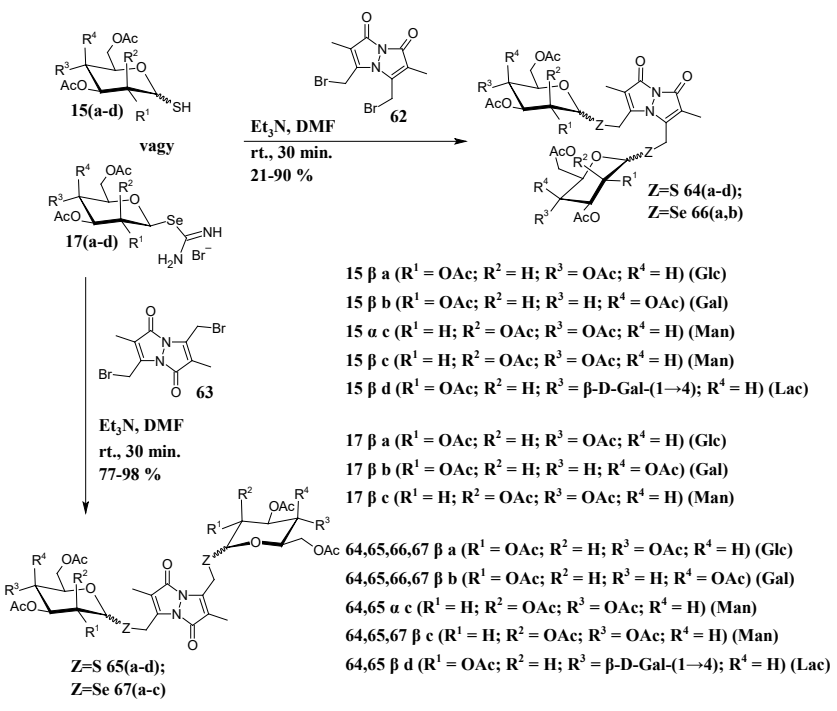

6. Ábra. Bimán központi vázas tio- és szeleno-glikozidok előállítása

Munkánk során néhány új kéntartalmú, nem glikozilezett bimán származékot is elöállítottunk, mint pl. a $\mathbf{6 8}$ szün- $\left(\mathrm{CH}_{2} \mathrm{SAc} ; \mathrm{CH}_{3}\right) \mathrm{B}, \quad 69$ szün- $\left(\mathrm{CH}_{2} \mathrm{SH} ; \mathrm{CH}_{3}\right) \mathrm{B}, 71$ an$t i$ - $\left(\mathrm{CH}_{2} \mathrm{SAc} ; \mathrm{CH}_{3}\right) \mathrm{B}$, illetve az intramolekuláris diszulfid hidat tartalmazó 70 szün- $\left(\mathrm{CH}_{2} \mathrm{~S}-; \mathrm{CH}_{3}\right) \mathrm{B}$ származék (7. ábra).

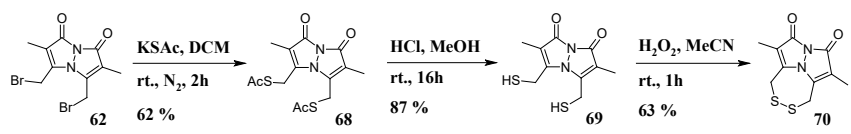

7. Ábra. szün-ditio bimán származékok elóállítása

Egy további interglikozidos kötés, a diszulfid híd kialakításával jutottunk $\mathbf{7 4 ( a - c ) ~ s z u ̈ n - ~}\left(\mathrm{CH}_{2} \mathrm{~S}_{2} \mathrm{GliAc}_{4} ; \mathrm{CH}_{3}\right) \mathrm{B}$ glikozilezett bimán származékokhoz. Bimán ditio-glikozidokat a 73(a-c) $N$-ftaloil- $S$-(2,3,4,6-tetra- $O$-acetil- $\beta$-Dglikopiranozil)szulfénamidok és 69 szün- $\left(\mathrm{CH}_{2} \mathrm{SH} ; \mathrm{CH}_{3}\right) \mathrm{B}$ bimán-ditiol reakciójával nyertünk. (8. ábra)

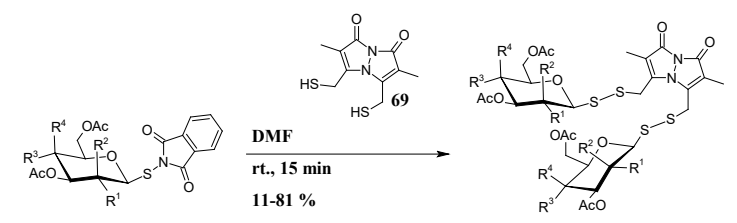

73 a $\left(\mathbf{R}^{1}=\right.$ OAc; $\mathbf{R}^{2}=\mathbf{H} ; \mathbf{R}^{3}=$ OAc; $\left.\mathbf{R}^{4}=\mathbf{H}\right)(\mathbf{G l c}) \quad 74$ a $\left(\mathbf{R}^{1}=\right.$ OAc; $\left.\mathbf{R}^{2}=\mathbf{H} ; \mathbf{R}^{3}=\mathbf{O A c} ; \mathbf{R}^{4}=\mathbf{H}\right)(\mathbf{G l c})$ 73 b ( $R^{1}=$ OAc; $R^{2}=\mathbf{H} ; \mathbf{R}^{3}=\mathbf{H} ; \mathbf{R}^{4}=$ OAc) (Gal) $74 \mathrm{~b}\left(\mathbf{R}^{1}=\right.$ OAc; $\mathbf{R}^{2}=\mathbf{H} ; \mathbf{R}^{3}=\mathbf{H} ; \mathbf{R}^{4}=$ OAc) (Gal) 73 c $\left(\mathbf{R}^{1}=\mathbf{H} ; \mathbf{R}^{2}=\right.$ OAc; $\mathbf{R}^{3}=$ OAc; $\left.\mathbf{R}^{4}=\mathbf{H}\right)$ (Man) $74 \mathrm{c}\left(\mathbf{R}^{1}=\mathbf{H} ; \mathbf{R}^{2}=\mathbf{O A c} ; \mathbf{R}^{3}=\mathbf{O A c} ; \mathbf{R}^{4}=\mathbf{H}\right)$ (Man)

8. Ábra. Bimán központi vázas diszulfido-glikozidok előállítása

További származékok előállítására a CuAAC („katt”) reakció, ${ }^{24,25}$ vonzó lehetőségnek mutatkozott, tekintettel a glikozilazidok könnyü hozzáférhetőségére. ${ }^{26}$ Valóban, a 79(a-d) per- $O$-acetil- $\beta$-D-glikopiranozil azidok és $\mathbf{7 8}$ szün- $\left(\mathrm{CH}_{3} ; \mathrm{C} \equiv \mathrm{CTMS}\right) \mathrm{B}^{27}$ reakciója jó hozamokkal szolgáltatta a 80(a-d) 1,2,3-triazolo glikozidokat. A 78 trimetilszilil csoportjai egy tandem reakcióban az azidokkal való kapcsolás során lehasadtak (9. ábra). ${ }^{28}$

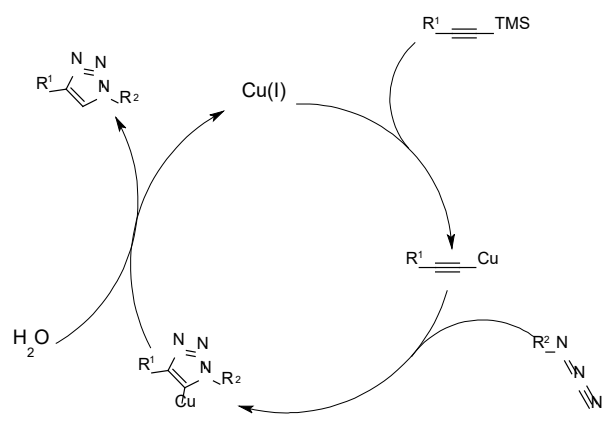

9. Ábra. Deszililezés és CuAAc dominó reakció katalitikus ciklusa

A 80(a-d) acetil csoportjait lítium-hidroxiddal eltávolítva kaptuk a 81(a-d) szabad cukor származékokat (10. ábra).

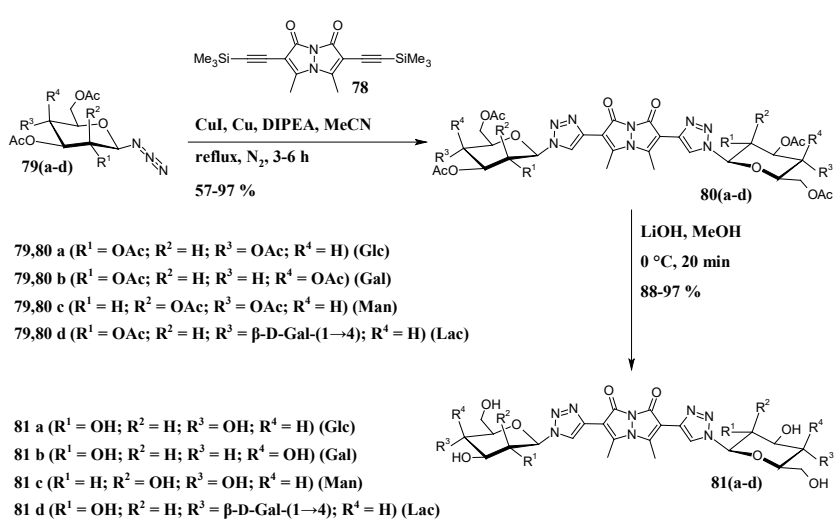

10. Ábra. Bimán központi vázas triazolo-glikozidok előállítása

\section{Glikozilezett bimán származékok jellemzése és biológiai aktivitása}

Vizsgálni kívántuk az alapvázhoz csatolt glikozil egységek fluoreszcenciára gyakorolt hatását. A glikozil egységek konfiguráció változtatásának nem volt észlelhető hatása a fluoreszcencia emissziós spektrumokra. A szün izomerek megtartották fluoreszcens tulajdonságaikat egy kivétellel: a 66(a,b) szeleno-glikozidokban megszünt az alapváz fluo- 


\begin{tabular}{|c|c|c|c|c|}
\hline \multirow[t]{2}{*}{ Vegyület } & & & \multirow[t]{2}{*}{$\begin{array}{l}\text { Abszorbció } \\
\lambda_{\max }, \mathrm{nm}\left(\varepsilon_{\max }\right)\end{array}$} & \multirow[t]{2}{*}{$\begin{array}{l}\text { Emisszió } \\
\lambda_{\max }, \mathrm{nm}\left(\Phi_{\mathrm{F}}\right)\end{array}$} \\
\hline & $\mathrm{R}^{2}$ & $\mathrm{R}^{1}$ & & \\
\hline 68(szün) & CH2SAc & $\mathrm{CH} 3$ & 375 (5600); $238(21100)$ & $445(0.86)$ \\
\hline $69($ szün $)$ & $\mathrm{CH} 2 \mathrm{SH}$ & $\mathrm{CH} 3$ & 375 (5400); 237 (14300) & $445(0.70)$ \\
\hline $\mathbf{7 0}(s z u ̈ n)$ & $\mathrm{CH} 2 \mathrm{~S}-$ & $\mathrm{CH} 3$ & 360 (4200); 232 (13100) & $442(0.74)$ \\
\hline 67(anti) & $C H 2 S e-\beta-G l c A c 4$ & $\mathrm{CH} 3$ & 335 (2800); $217(5100)$ & nem fluoreszcens \\
\hline 66(szün) & CH2Se- $\beta$-GlcAc4 & $\mathrm{CH} 3$ & $360(800) ; 237$ (26100) & nem fluoreszcens \\
\hline $65($ anti) & CH2S- $\beta-G l c A c 4$ & $\mathrm{CH} 3$ & 333 (2500); 206 (3900) & nem fluoreszcens \\
\hline 64(szün) & $C H 2 S-\beta-G l c A c 4$ & $\mathrm{CH} 3$ & $364(5100) ; 255$ (23100) & $444(0.89)$ \\
\hline 74(szün) & $C H 2 S 2-\beta-G l c A c 4$ & $\mathrm{CH} 3$ & 378 (4600); 245 (13200) & $449(0.57)$ \\
\hline $\mathbf{8 0}(s z u ̈ n)$ & $\mathrm{CH} 3$ & $T A-\beta-G l c A c 4$ & 411 (3500); $242(4400)$ & $475(0.86)$ \\
\hline
\end{tabular}

2. Táblázat. Bimán származékok UV-Vis és fluoreszcens tulajdonságai

reszcenciája, nagy valószínüséggel a szelén és a bimán fluorofór között végbemenő fotoindukált elektron transzfernek (PET) köszönhetően ${ }^{29}$ (2. táblázat).

A 64 szün- $\left(\mathrm{CH}_{2} \mathrm{SGlcAc}_{4} ; \mathrm{CH}_{3}\right) \mathrm{B}, 65$ anti- $\left(\mathrm{CH}_{2} \mathrm{SGlcAc}_{4} ; \mathrm{CH}_{3}\right)$ $\mathrm{B}, 68$ szün- $\left(\mathrm{CH}_{2} \mathrm{SAc} ; \mathrm{CH}_{3}\right) \mathrm{B}, \quad \mathbf{7 0}$ szün- $\left(\mathrm{CH}_{2} \mathrm{~S}-; \mathrm{CH}_{3}\right) \mathrm{B}, \mathbf{8 0}$ szün- $\left(\mathrm{CH}_{3} ; \mathrm{TAGlcAc}_{4}\right) \mathrm{B}$ bimán származékok szerkezetének további jellemzésére Dr. Bényei Attila (Debreceni Egyetem Fizikai Kémiai Tanszék) végzett egykristály röntgendiffrakciós méréseket. Az általunk vizsgált kristályokban gyakran két független molekula detektálható aszimmetrikus egységként. A bimán vázat alkotó két anellált pirazolon gyürü nincs egy síkban, az eltérés 0-50 fok között változik. ${ }^{30}$ A két pirazolon gyürü síktól való eltérése az aszimmetrikus egységben található két molekulára is különbözö, pl. 68 szün- $\left(\mathrm{CH}_{2} \mathrm{SAc} ; \mathrm{CH}_{3}\right)$ B esetében 13/22 fok, a 64 szün- $\left(\mathrm{CH}_{2} \mathrm{SGlcAc}_{4} ; \mathrm{CH}_{3}\right)$ B esetén $5 / 19$ fok, míg az intramolekuláris diszulfid hidas 70 szün- $\left(\mathrm{CH}_{2} \mathrm{~S}-; \mathrm{CH}_{3}\right) \mathrm{B}$ molekulában 4/19 fok. A két cukor egység anomer szénatomjai közötti távolság tág határok között változik: a 65 anti-(CH$\left.{ }_{2} \mathrm{SGlcAc}_{4} ; \mathrm{CH}_{3}\right) \mathrm{B}$ esetében $5.9 \AA$ a 80 szün- $\left(\mathrm{CH}_{3} ; \mathrm{TAGlcAc}_{4}\right)$ B származékban $14.0 \AA$ (11. ábra). ${ }^{22}$

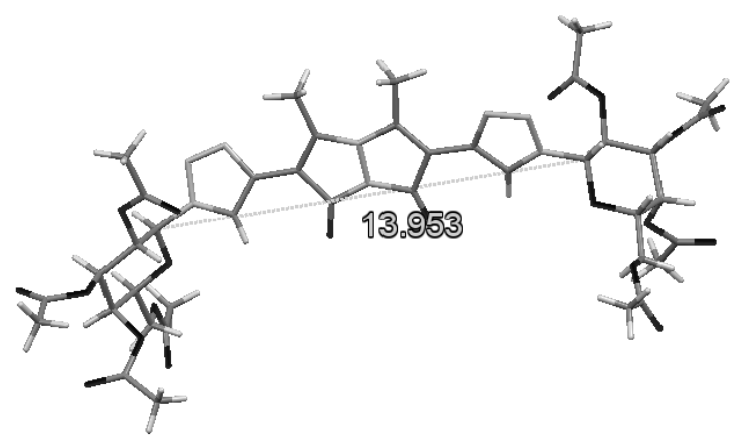

11. Ábra. 80a szün- $\left(\mathrm{CH}_{3} ; \mathrm{TAGlcAc}_{4}\right) \mathrm{B}$ triazolo-glikozid anomer szeneinek távolsága $(\AA)$

Az előállított bimán alapvázas glikozil mimetikumok biológiai aktivitását Dr. Marcelo Comini és munkatársai vizs- gálták, a Montevideo-i Pasteur Intézetben. Azt tapasztalták, hogy a 69 szün- $\left(\mathrm{CH}_{2} \mathrm{SH} ; \mathrm{CH}_{3}\right) \mathrm{B}, 70$ szün- $\left(\mathrm{CH}_{2} \mathrm{~S}-; \mathrm{CH}_{3}\right)$ $\mathrm{B}, 68$ szün- $\left(\mathrm{CH}_{2} \mathrm{SAc} ; \mathrm{CH}_{3}\right) \mathrm{B}$ és $64 \beta \mathrm{c}$ szün- $\left(\mathrm{CH}_{2} \mathrm{~S}-\beta-\mathrm{Ma}-\right.$ $\left.\mathrm{nAc}_{4}, \mathrm{CH}_{3}\right) \mathrm{B}$ származékok közepes hatékonysággal gátolták az afrikai álomkórért felelős Trypanosoma brucei parazita szaporodását.

\section{7. Összefoglalás}

A sejtfelszíni glikánok és lektinek közötti felismerési folyamatok mélyebb megértéséhez olyan új glikokonjugátumokat állítottunk elö, amelyekben a szénhidrát egységeket az $O$-glikozidos kötés oxigénje helyett $S / S e$ és diszulfid híddal kapcsoltuk a központi aromás vázakra alkalmazott (benzol-, naftalin).

Az új bivalens glikomimetikumokat a VAA növényi toxin blokkolására, illetve a sejtek adhézióját/növekedését szabályozó humán galektinek gátlása céljából állítottuk elő. Egyes esetekben az alap szénhidráthoz viszonyítottan százszoros inhibíciós aktivitást lehetett mérni. Az eredmények alapján a tanulmányozott szénhidrát mimetikumok lehetővé teszik fiziológiailag releváns kölcsönhatások vizsgálatát.

További munkánk során egy sor új fluoreszcens és nem fluoreszcens glikokonjugátumot állítottunk elő és jellemeztünk, amelyekben mono- és diszacharid egységeket kapcsoltunk az 1,5-diazabiciklo[3.3.0]okta-3,6-dién-2,8dion (bimán) heteroaromás gyürürendszerhez. A szün- és anti-bimán központi vázra mono- és diszacharid egységeket tio-, ditio- és szeleno-glikozidos kötéssel kapcsoltuk. További bivalens bimán szénhidrát származékokat nyertünk glikozil azidok és bimán dietinil származékának CuAAC katalizálta reakciójából, ezekben a központi bimán vázra a cukor egységek 1,2,3-triazol gyürűvel kapcsolódtak. Egykristály röntgendiffrakciós mérésekkel jellemeztük néhán glikozilezett és nem glikozilezett bimán származék kristály- és molekulaszerkezetét. 


\section{Köszönetnyilvánítás}

Ezúton szeretném megköszönni témavezetőmnek Prof. Dr. Szilágyi Lászlónak a jó tanácsokat és folyamatos segítségét. Köszönetem fejezem ki Prof. Dr. Hans-Joachim Gabiusnak, Dr. Marcelo Comininek és munkatársaiknak a biológiai vizsgálatokért, Dr. Fehér Krisztinának a molekulamodellezési számításokért, Dr. Bényei Attilának a röntgenkrisztallográfiai szerkezet meghatározásokért, Balla Sárának az NMR és Dr. Kiss Attilának az MS mérésekért. Szeretném megköszönni Garadnay Sándornak, Náray Zsófiának, Dr. Greiner Istvánnak, és a Richter Gedeon Nyrt.-nek, hogy támogatták a képzésemet. A kutatás a Richter Gedeon Nyrt, az OTKA NN-109671, a GINOP-2.3.2-15-2016-00008, és GINOP-2.3.3-15-2016-00004 számú projektek keretében, az utóbbi esetében az Európai Unió támogatásával, az Európai Regionális Fejlesztési Alap társfinanszírozásával valósult meg.

\section{Hivatkozások}

1. D. T. Tran; H. K. G. Ten, J. Biol. Chem. 2013, 61, 6921-6929. https://doi.org/10.1074/jbc.R112.418558

2. H-J. Gabius, Trends Biochem. Sci. 2015, 40, 341. https://doi.org/10.1016/j.tibs.2015.04.003

3. H-J. Gabius; J. Roth, Histochem. Cell. Biol. 2017, 147, 111-117. https://doi.org/10.1007/s00418-016-1521-9

4. Y. M. Chabre; R. Roy; H-J. Gabius, The sugar code Fundamentals of glycosciences, Weinheim, Germany: Wiley-VCH 2009. ISBN:978-3-527-32089-9

5. H-J. Gabius; H. Kaltner; J. Kopitz; S. André, Trends Biochem. Sci. 2015, 40, 360-376. https://doi.org/10.1016/j.tibs.2015.03.013

6. J. C. Manning; A. Romero; F. Habermann; C. G. García; H. Kaltner; H-J. Gabius, Histochem. Cell. Biol. 2017, 147, 199-222.

https://doi.org/10.1007/s00418-016-1524-6

7. J. Roth; C. Zuber, Histochem. Cell. Biol. 2017, 147, 269-284. https://doi.org/10.1007/s00418-016-1513-9

8. A „lektin” (lectin) elnevezés W. C. Boyd-tól származik: W. C. Boyd, Vox Sang. 1963, 38, 1-32. https://doi.org/10.1111/j.1423-0410.1963.tb04146.x

9. R. Krauspenhaar; S. Eschenburg; M. Perbandt; V. Kornilov; N. Konareva; I. Mikailova; S. Stoeva; R. Wacker; T. Maier; T. Singh; A. Mikhailov; W. Voelter; C. Betzel, Biochem. Biophys. Res. Commun. 1999, 257, 418-424. https://doi.org/10.1006/bbrc.1999.0470

10. H-J. Gabius; J. C. Manning; J. Kopitz; S. André; H. Kaltner, Cell. Mol. Life Sci. 2016, 73, 1989-2016. https://doi.org/10.1007/s00018-016-2163-8

11. A. A. Klyosov; Z. A. Witzhak; D. Platt, Galectins, John Wiley \& Sons: Hoboken, NJ, 2008. ISBN:978-0-470-37318-7

12. L. Song; Y. Yangsheng; D. K. Christopher; Z. Zhixin; S. Kaihong, J. Clin. Cell Immunol. 2013, 4, 164 https://doi.org/10.4172/2155-9899.1000164

13. S. Toegel; D. Weinmann; S. André, J. Immunol. 2016, 196, 1910-1921.

https://doi.org/10.4049/jimmunol.1501165
14. A. Klyosov; P. G. Traber, Galectins and Disease Implications for Targeted Therapeutics, ACS Symposium Series 2012, 1114. https://doi.org/10.1021/bk-2012-1114.ch004

15. M. Buerke; A. S. Weyrich; Z. Zheng; F. C. Gaeta; M. J. Forrest; A. M. Lefer, J. Clin. InVest. 1994, 93, 1140-1148. https://doi.org/10.1172/JCI117066

16. K. M. Beeh; J. Beier; M. Meyer; R. Buhl; R. Zahlten; G. Wolff, Pulm Pharmacol Ther. 2006, 19, 233-241. https://doi.org/10.1016/j.pupt.2005.07.004

17. V. L. Campo; M. F. Marchiori; L. C. Rodriguez; M. DiasBaruffi, Glycoconjugate J. 2016, 33, 853-876. https://doi.org/10.1007/s10719-016-9721-z

18. C-I. Lin; E. E. Whang; D. B. Donner; X. Jiang; B. D. Price; A. M. Carothers; T. Delaine; H. Leffler; U. J. Nilsson; V. Nose; F. D. Moore Jr.; D. T. Ruan, Mol. Cancer Res. 2009, 7, $1655-1652$. https://doi.org/10.1158/1541-7786.MCR-09-0274

19. V. V. Glinsky; G. Kiriakova; O. V. Glinskii; V. V. Mossine; T. P. Mawhinney; J. R. Turk; A. B. Glinskii; V. H. Huxley; J. E. Price; G. V. Glinsky, Neoplasia 2009, 11, 901-909. https://doi.org/10.1593/neo.09594

20. K. Bum-Erdene; I. A. Gagarinov; P. M. Collins; M. Winger; A. G. Pearson; J. C. Wilson; H. Leffer; U. J. Nilsson; I. D. Grice; H. Blanchard, ChemBioChem. 2013, 14, 1331-1342. https://doi.org/10.1002/cbic.201300245

21. H. Kaltner; T. Szabó; K. Fehér; S. André; S. Balla; J. C. Manning; L. Szilágyi; H-J. Gabius, Bioorg. Med. Chem. 2017, 25, 3158-3170. https://doi.org/10.1016/j.bmc.2017.04.011

22. T. Szabó; L. Szilágyi; A. Bényei, Carbohydr. Res. 2019, 473, 88-98. https://doi.org/10.1016/j.carres.2019.01.002

23. E. M. Kosower; B. Pazhenchevsky; E. Hershkowitz, J. Am. Chem. Soc. 1978, 100, 6516-6518. https://doi.org/10.1021/ja00488a050

24. V. V. Rostovtsev; K. G. Green; V. V. Fokin; K. B. Sharpless, Angew. Chem. Int. Ed. 2002, 41, 2596-2599.

https://doi.org/10.1002/15213773(20020715)41:14<2596::AID-ANIE2596>3.0.CO;2-4

25. C. W. Tornøe; C. Christensen; M. Meldal, J. Org. Chem. 2002, 67, 3057-3064. https://doi.org/10.1021/jo011148j

26. Z. Györgydeák; J. Thiem, Adv. Carbohyd. Chem. Biochem. 2006, 60, 103-182. https://doi.org/10.1016/S0065-2318(06)60004-8

27. E. M. Kosower; B-S. Marcia, J. Org. Chem. 1996, 61, 5871-5884. https://doi.org/10.1021/jo951830b

28. F. Cuevas; A. I. Oliva; M. A. Pericàs, Synlett 2010, 12, 1873-1877. https://doi.org/10.1055/s-0030-1258120

29. H. Jiang; L. Jia; Y. Li; S. Liu; R. Chen; L. Jin; J. Jin; C. Zheng; Q. Fan; W. Huang, Chem. Commun. 2018, 54, 2926-2929. https://doi.org/10.1039/C8CC01267A

30. I. Goldberg; E. M. Kosower, J. Phys. Chem. 1982, 86, 332-335. https://doi.org/10.1021/j100392a011 


\section{Syntheses of sulfur- and selenium containing glycomimetics}

The glycan structures on the surface of living cells harbor enormous amounts of information by virtue of their vast variety of sequence, branching, and stereochemical patterns. Lectin proteins are participating in essential biochemical/biophysical processes such as intracellular signalling, cell-cell or cell-intracellular matrix interactions via binding to cell-surface glycans. Galectins, an important class of animal/human lectins, are responsible for a range of pathological processes such as rheumatoid arthritis, inflammations, fibrosis or cancer.

Small-medium sized molecules, known as carbohydrate mimetics or glycoconjugates, play an important role in the elucidation of the molecular mechanisms of lectin-glycan interactions. Therefore, the main objective of the investigations described in my $\mathrm{PhD}$ thesis was to synthesize novel glycoconjugates with the potential to inhibit toxic plant agglutinins and/or harmful animal/human lectins, in particular, galectins.

For this purpose carbohydrate derivatives characterized by the attachment of mono- or disaccharides to central aromatic or heteroaromatic cores such as benzene, naphthalene or 1,5-diazabiccylo[3.3.0]octa-3,7-diene-2,6-dione (,bimane”) were synthesized. To avoid potential decomposition of these compounds by hydrolases or other carbohydrate-processing enzymes the glycosidic oxygen was replaced by non-oxygen atoms or fragments resistant to hydrolysis such as thio-, seleno- or disulfido glycosidic linkages, or 1,2,3-triazolo rings.

The novel bivalent thio-, disulfido- and selenoglycosides attached to benzene/naphthalene cores display galactose, for blocking the plant toxin VAA, or lactose, the canonical ligand of adhesion/ growth-regulatory human galectins.

Reactions of bis(bromomethyl)arenes with per- $O$-acetyl-D-glycopyranosyl thiols or -selenouronium bromides furnished bis-thioglycosides or selenoglycosides, respectively. Disulfidoglycosides were obtained similarly via reacting glycosyl precursors with bismethanethiosulfonic acid esters, see (Figures 3-4.)

The anticipated lectin inhibitory activities could indeed be confirmed by using biochemical/physical techniques such as solid-pha- se assays with a surface-presented glycoprotein or flow cytofluorimetric analysis to demonstrate prevention of lectin binding to surfaces of human carcinoma cells and histochemical assays on murine organ tissue sections as models. Activity enhancements per sugar unit were detected to an extent of up to nearly 100 fold relative to free cognate sugar.

The results open perspectives for extended applicability of the studied glycoclusters in testing physiologically relevant interactions of biomedically relevant lectins.

In a further study syntheses and characterization of a set of novel glycoconjugates derivatives with appended mono- and disaccharide moieties, based on the 1,5-diazabicyclo[3.3.0]octa-3,6diene-2,8-dione (bimane) heteroaromatic ring system have been described. No carbohydrate derivatives of bimanes have been described before. Mono- and disaccharide precursors were reacted with syn- and anti-dibromobimanes to obtain (bis)thio-, dithio- or selenoglycosides as shown in (Figure 6.) $\mathrm{Cu}(\mathrm{I})$-catalyzed cycloaddition of glycosyl azides to a bimane diethinyl derivative furnished further bivalent glycoconjugates with sugar residues linked to the central bimane core via 1,2,3-triazole rings (Figure 10.). Crystal and molecular structures of several glycosylated and non-glycosylated bimanes have been determined together with fluorescence data for the new compounds. Crystallographic analysis in several cases revealed nonplanarity of the bimane skeleton, ie. the angle subtended by the mean planes of the two pyrazolone rings varying between 0-50 deg. Distances between the glycosyl units, characterized by the separation of anomeric $\mathrm{C}$-atoms, are varying within an extended range from 5.9- to $14.0 \AA$ (Figure 11.).

Potential applications with carbohydrate-binding proteins, such as lectins, or more complex biological systems are forseen particularly in view of the fluorescent properties of these molecules.

Preliminary assays have indicated moderate inhibition activity on the growth of Trypanosoma brucei parasite, the causing agent of African sleeping disorder for some of our novel derivatives such as 69 syn- $\left(\mathrm{CH}_{2} \mathrm{SH} ; \mathrm{CH}_{3}\right) \mathrm{B}, 70$ syn- $\left(\mathrm{CH}_{2} \mathrm{~S}-\mathrm{CH}_{3}\right) \mathrm{B}, 68$ syn- $(\mathrm{CH}-$ $\left.{ }_{2} \mathrm{SAc} ; \mathrm{CH}_{3}\right) \mathrm{B}$ and $\mathbf{6 4 \beta c}$ syn- $\left(\mathrm{CH}_{2} \mathrm{~S}-\beta-\mathrm{ManAc}_{4}, \mathrm{CH}_{3}\right) \mathrm{B}$. 